Отримано: 7 березня 2018 р.

Прорецензовано: 12 березня 2018 р.

Прийнято до друку: 19 березня 2018 р.

e-mail: kra_nat@ukr.net

DOI: $10.25264 / 2519-2558-2018-1(69) / 1-225-228$

Nataliia Kramar. Humor in "The feynman lectures on physics": typology and pragmatic functions. Наукові записки Національного університету «Острозька академія»: серія «Філологія». Острог : Вид-во НаУОА, 2018. Вип. 1(69), ч. 1, березень. С. 225-228.

УДК: 81 ' $42: 811.11+81-7$

Nataliia Kramar,

Center for Scientific Research and Teaching of Foreign Languages of the National Academy of Sciences of Ukraine, Kyiv

\title{
HUMOR IN “THE FEYNMAN LECTURES ON PHYSICS”: TYPOLOGY AND PRAGMATIC FUNCTIONS
}

The present paper deals with the use of humor by Richard P. Feynman in his famous and still popular Lectures on Physics, presented to undergraduate students at Caltech in 1961-63. Modern perspectives on humor in academic discourse are discussed, with various taxonomies of humor types being compared. It is suggested that the underlying rhetorical mechanism and the availability of deprecation should be construed as the main criteria when classifying humor in lectures and other academic events with uneven power balance. It is established that R.P. Feynman often resorts to deprecatory humor targeted towards Humanities, which he did not believe to be true science. This type of humor functions to draw the line between the in-group (the participants) and the out-group (the others), thus enhancing the solidarity in the former one. In terms of rhetoric, R. P. Feynman mostly uses irony, comparison/contrast and hyperbole to create humorous effect. Far from being merely entertainment, humorous comments perform important pragmatic functions, such as establishing rapport, focusing the attention of the audience, and making the content more memorable.

Key words: humor, R.P. Feynman, lectures, academic discourse, pragmatic function.

Крамар Наталія Анатоліївна,

Центр наукових досліджень та викладання іноземних мов НАН Украӥни, м. Київ

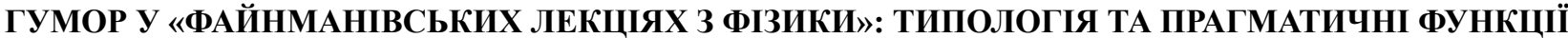

У статті висвітлюються особливості використання гумору у лекціях з фізики відомого американського вченого, Нобелівського лауреата Р. Ф. Файнмана. Встановлено, що основними риторичними механізмами, які лежать в основі авторського гумору, $\epsilon$ іронія, порівняння і контраст, гіпербола. Хоча у лекиіях переважає доброзичливий гумор, Файнман допускає і осудливі гумористичні коментарі на адресу представників гуманітарних наук, до яких він ставився критично. Гумор у лекиіях виконує иілу низку прагматичних функиій, серед яких зміинення солідарності учасників лекиій шляхом визначення «чужого», фокусування уваги аудиторії, зменшення формальності та викладення матеріалу у легшій для запам'ятовування формі.

Ключові слова: гумор, Р.Ф. Файнман, лекиії, науковий дискурс, прагматична функиія.

Крамар Наталия Анатольевна,

Центр научных исследований и преподавания иностранных языков НАН Украины, г. Киев

\section{ЮМОР В «ФАЙНМАНОВСКИХ ЛЕКЦИЯХ ПО ФИЗИКЕ»: ТИПОЛОГИЯ И ПРАГМАТИЧЕСКИЕ ФУНКЦИИ}

В статье освещаются особенности использования юмора в лекциях по физике известного американского ученого, Нобелевского лауреата Р. Ф. Файнмана. Установлено, что главными риторическими механизмами, которые лежат в основе авторского юмора, являются ирония, сравнение и контраст, гипербола. Хотя в лекциях преобладает доброжелательньй юмор, Файнман допускает и осуждающие юмористические комментарии в адрес представителей гуманитарных наук, к которым он относился критически. Юмор в лекциях выполняет цельй ряд прагматических функций, среди которых укрепление солидарности участников лекиий путем определения «чужого», фокусирование внимания аудитории, уменьшение формальности и изложение материала в легкой для запоминания форме.

Ключевые слова: юмор, Р. Ф. Файнман, лекиии, научный дискурс, прагматическая функция.

Humor as an imminent feature of human communication has long concerned linguists, philosophers and psychologists alike. But it's only since recently that scholars have turned their attention to the use of laugher in education. While humor is rarely employed in classroom on a conscious level, it certainly provides a vast number of pedagogical benefits, especially given the contemporary communicative model of teaching [1,45]. As noted by Attardo, a salient figure in humor research, the most crucial function of humor is to generate and enhance solidarity between the participants, while also creating in- and out-groups [2]. It was found to increase students' information retention [5] and to enhance their enjoyment of the subject [12]. Having analyzed the instances of lecturerprompted laughter in the MICASE, the BASE and the ELC corpuses, Hilary Nesi revealed that it helped greatly to build lecturerstudent rapport, relieve tension, maintain social order and mold professional identities $[10,88]$. Similar conclusions were drawn by D. Lee, who studied humor in terms of lecture comprehension [7, 49]. He also notes that using humor in classroom is part of the global informalization process that encompasses all academic levels, from college seminars to thesis defenses. Humor, therefore, seems a perfect vehicle for the so-called edutainment, a hybrid of education and entertainment, which is sometimes viewed as a new genre of lecturing $[11,1]$.

In the present study we intend to explore the use of humor in the Lectures on Physics by a renowned scientist and Nobel laureate Richard P. Feynman. What makes Feynman a particularly suitable figure for such an investigation is his adventurous character, extreme curiosity and love for practical joking that all his friends were accustomed to. Apart from being an extraordinary person, Feynman was an extraordinary lecturer: the simplicity of his lectures earned him the title of "Great Explainer" [8]. The Feynman Lectures on Physics, based on the course he delivered to undergraduate students in Caltech in 1961-63, became his most widely-read 
book that has not lost its popularity ever since. Our aim is to analyze the way R. P. Feynman uses humor in the classroom setting, with particular focus on its pragmatic functions.

For the purpose of our research, we adopt the broad definition of humor by J. Holmes: "utterances which are identified by the analyst, on the basis of paralinguistic, prosodic and discoursal clues, as intended by the speaker(s) to be amusing and perceived to be amusing by at least some participants" $[6,163]$. According to D. Lee, lecture is one of the most laughter-scarce events among academic speech genres, as compared to seminars, meetings, student presentations, tutorials and other events with stronger interactive component [7, 54]. Feynman's lectures turned out to be no exception in this respect: we identified only 108 humor elements in the three volumes of lectures, which comprise 812,000 words. Taking into consideration the general number of lectures (115), it totals to one humorous remark per lecture. It means that R.P. Feynman definitely discerned between the academic and the everyday setting in molding his discourse and did not rely on humor as a pedagogical means too much.

Quite different typologies of humor can be met in the literature on academic discourse, with no stone-set pattern to follow. Based on the MICASE corpus, David Lee identifies seven types of humor: self-effacing jokes and in-jokes; sarcastic and tongue-in-cheek comments; mixed lexis or registers, wit and uncommon turns of phrase; comic comparisons and contrasts; references to youth culture; hyperbole and exaggeration [7,56]. Hilary Nesi, who analyzed three main academic English corpora, comes up with a quite different taxonomy: teasing, lecturer error, disparagement, black humor, self-deprecation, and wordplay [10, 79]. Based on our sample, we believe it is certainly necessary to discern between deprecatory and non-deprecatory humor, on the one hand, and to consider the rhetorical mechanism that lies in the foundation of the humorous strategy, on the other hand. Concerning the first criterion, 17 out of 108 humorous elements turned out to be deprecatory towards other people or communities and 1 was found to be self-deprecatory. The self-deprecatory comment reads as follows:

"That is all my teacher told me, because he was a very good teacher and knew when to stop talking. But I don't know when to stop talking”. (Vol. II, Lecture 19)

In this case, R. P. Feynman reproaches himself for too much talkativeness, thus revealing that he is not blameless and becoming closer to his students. In general, as pointed by Nesi, self-deprecation signals "modesty and approachability", though it may at times also serve the opposite purpose of implicit self-aggrandizement [10,85]. However, humility is very rare to be seen in the Lectures: Feynman is mostly critical of others than of himself. In the following example R. P. Feynman is slightly denigrating women, positioning them as fickle creatures:

"Some changes are more difficult to describe than the motion of a point on a solid object, for example the speed of drift of a cloud that is drifting very slowly, but rapidly forming or evaporating, or the change of a woman's mind." (Vol. I, Lecture 8)

Feynman also tells to his students a joke about a cop and a silly female driver, who replies to the cop's accusation of speed driving in such a way: "It is ridiculous-how can I go 60 miles an hour when I wasn't going an hour?" As mentioned in Feynman's memoir, this harmless joke cost Feynman allegations of sexism from a feminist group [4, 50]. Although being quite ludicrous, this incident shows how careful lecturers should be when choosing words and jokes to tell their students, especially in modern democratic society when much (and sometimes even too much) value is put on tolerance and equality.

Another object of Feynman's deprecatory humor is the representatives of the opposite research camp - the Humanities, particularly philosophers and psychologists. Feynman was always "a technical guy" with neither liking nor understanding of the humanities. He openly despised philosophers and considered them "inane" [3,151]. Even in the lectures, he can't pass them by in silence: we've found 6 instances of deprecatory humor directed at philosophers and philosophy, e.g.:

"We cannot define anything precisely! If we attempt to, we get into that paralysis of thought that comes to philosophers, who sit opposite each other, one saying to the other, "You don't know what you are talking about!" (Vol. I, Lecture 8)

"When this idea descended upon the world, it caused a great stir among philosophers, particularly the "cocktail-party philosophers," who say, "Oh, it is very simple: Einstein's theory says all is relative!" (Vol. I, Lecture 16)

"When this is told to a philosopher, he is very upset that he did not really understand it, because to him it seems impossible that one should be able to determine rotation about an axis without looking outside." (Vol. I, Lecture 16)

In one case, the object of Feynman's deprecatory humor is psychology, which he also believed to be close to pseudoscience:

"So that is the situation in the psychological analysis of this matter: if everybody says there are three, and somebody says there are four, and they want it to be four, it will be four. That shows the difficulty with psychological researches." (Vol. I, Lecture 36)

Deprecatory humor performs the function of creating in- and out-groups, which Attardo claims to be one of the main functions of humor in general [2]. The disparagement of out-group members (in this case, women, philosophers and psychologists) serves to bond participants and strengthen in-group identity, while also fostering a sense of superiority [7, 86]. The undergraduate Physics students that Feynman lectured to were thus encouraged to mold the identity of an elite group of society that discussed the matters which were far beyond the grasp of others. Certainly, such form of humor may not always be acceptable: though Feynman got away with it, modern lecturers can get into troubles for bolstering the in-group identity of their students at the expense of others.

On the other hand, physicists and engineers also take the blow in Feynman's Lectures: 4 out 108 instances of humor deride precisely the field that the students are supposed to work in, e.g.:

"So you see, this physics of ours is a lot of fakery-we start out with the phenomena of lodestone and amber, and we end up not understanding either of them very well." (Vol. II, Lecture 37)

"The reason that the engineers like to do this is that they learned something when they were young: V=RI for resistances, when they only knew about resistances and $d c$. [...] it is a miracle that they did not insist also that the letter Z be an R!' (Vol. I, Lecture 23)

Therefore, the elitism that students might have begun developing is balanced out with a more rational and self-critical attitude to their specialty. Feynman urges them to understand that the hard sciences do not have answers to all the questions one may put, nor are they immune to mistakes and limitations of other sciences.

As concerns the rhetorical essence of humorous elements in Feynman's lectures, most of them were found to be based on irony (42 occurrences), comparison and contrast (16 occurrences), hyperbole (15 occurrences), and sarcasm ( 8 occurrences). Irony, which is merged with sarcasm in Lee's classification [7], is the most salient type of humor in Feynman's lectures. It primarily appears in the explication of theoretical content, while we also come across this type of humor in the introductory and concluding phases: 
"For this reason poor old Einstein was called the "father" of the atomic bomb in all the newspapers." (Vol. I, Lecture 16)

"Remember them in case you are ever on a desert island." (Vol. II, Lecture 26)

"Are all the laws of physics reversible? Evidently not! Just try to unscramble an egg!" (Vol. I, Lecture 46)

If we blow on the water so as to maintain a continuous preponderance in the number evaporating, then the water is cooled. Hence, blow on soup to cool it! (Vol. I, Lecture 1)

In the last two examples, it can be seen that the humorous effect is often created by associating high-brow theoretical issues with trifling everyday matters, thus adding the rhetorical element of meiosis (understatement).

Humorous comparisons and contrasts, even though they may be incongruous, are an effective means to make academic content more memorable $[7,59]$. In the examples below, Feynman alludes to the image of Cinderella and to old grandfather's clock that are sure to evoke childhood memories in the audience:

"[...] ]one kind of chemical "fits" into the enzyme, but the other kind does not (like Cinderella and the slipper, except that it is a "left foot" that we are testing)." (Vol. I, Lecture 52)

"In other words, if we build a piece of equipment in some place and watch it operate, and nearby we build the same kind of apparatus but put it up on an angle, will it operate in the same way? Obviously it will not if it is a Grandfather clock, for example!" (Vol. I, Lecture 11)

Humorous hyperbolization is also common in Feynman's lectures. According to Lee, hyperbolic humor is rare to be found in spoken academic discourse, especially as concerns overgeneralizations, exaggerations in number and exaggerations to extreme extent $[7,61]$. The hyperbole we encounter in Feynman's lectures is of different kind: in most cases it lies in the use of strong emphatic words instead of neutral ones, which are typically more expected in the academic discourse, or in the emotional concurrence of synonyms:

"So instead of leaving it as an interesting remark, I am going to horrify and disgust you with the complexities of life by proving that it is so." (Vol. II, Lecture 19)

"Now, is it absolutely, definitely, philosophically necessary that one should not be able to tell how fast he is moving without looking outside?" (Vol. 1, Lecture 16)

A peculiar way of hyperbolization, which seems specific to Feynman, is calling something a miracle or miraculous:

"It is a miracle of good luck that we can associate a single axis with a plane, and therefore that we can associate a vector with the torque." (Vol. I, Lecture 20)

The major function performed by hyperbolic humor is reducing the formality since the lecturer positions himself as an emotional being, thus becoming more approachable for the students. Another way of sparking humor in Feynman's lectures is mixing lexis and registers of speech, which is also featured in Lee's study [7]. In taking his stance on debatable theoretical issues, he often resorts to colloquial words and phrases, e.g.:

"Finally, in order to really convince you that this theory is obviously nuts, we will take one more example." (Vol. II, Lecture 27)

"[... ] these are obviously particles, for anybody's money!" (Vol. I, Lecture 38)

This type of humor, similarly to hyperbolization, makes the lecturer seem more accessible and friendly to his students as he turns to "talk their language". According to Nesi, inserting informal words into otherwise formal context benefits the lecturer's positive face by creating the impression of spontaneity and unstuffiness $[2,86]$.

It is worth noting that R.P. Feynman is not afraid to resort to some of the most controversial types of humor, i.e. black humor and religious humor. Talking about the diagram invented by Stevinus (a Flemish mathematician) and inscribed on his tombstone, the lecturer makes the following aside:

"If you get an epitaph like that on your gravestone, you are doing fine." (Vol. I, Lecture 4)

Religion becomes an object of humorous remarks mostly when Feynman tells his students of the matters that are hardly explainable to scientists. He refers to "demons", "angels" and "omnipotent being", whose involvement might clear the things up. The irony was obvious to his audience, though, as Feynman always declared himself an atheist despite his Jewish background.

Finally, the varieties of humor that are conspicuous by their absence in Feynman Lectures on Physics are student teasing, mock threats and bawdy humor. He maintained decent and reserved manner of speaking throughout, without trying to earn the respect of his audience by buffoonery or insults. Of the four psychological styles of humor [9], he only applies self-enhancing and affiliative styles, but never self-defeating or aggressive humor.

In conclusion, benign humor is one of the robust and often underestimated means of establishing rapport between teachers and students at any level of study. Though no single methodology and taxonomy for analyzing humorous remarks has been developed yet, we suggest that it is important to identify the rhetorical mechanism that lies in the basis of humorous remarks, while also taking into account whether it's deprecatory or not. In Feynman Lectures on Physics, the major type of humor is irony, followed by comparison/contrast and hyperbole. The deprecatory remarks are predominantly targeted towards philosophy and psychology, which Feynman perceived rather skeptically. In the lecture discourse, they perform the function of bolstering the solidarity of the lecture participants by creating in and out-groups. Other pragmatic functions that humor is responsible for in Feynman Lectures are reducing formality, creating an approachable image, focusing students' attention and making the content memorable. Further research in this area might compare the use of humor in the works of several famed scientists or analyze humor in academic discourse in crosscultural perspective.

\section{Sources of Illustrative Material:}

Feynman R. P. Feynman Lectures on Physics / R. P. Feynman. - The California Institute of Technology, 2013. - Retrieved from http:// www.feynmanlectures.info/

\section{References:}

1. Askildson L. Effect of Humor in the Language Classroom: Humor as a Pedagogical Tool in Theory and Practice / L. Askildson // Second Language Acquisition and Teaching (SLAT). - 2005. - Vol. 12. - P. 45-61.

2. Attardo S. Humor in Language / S. Attardo // Oxford Research Encyclopedias: Linguistics. - Mar 2017. - Retrieved from http:// linguistics.oxfordre.com/view/10.1093/acrefore/9780199384655.001.0001/acrefore-9780199384655-e-342 
3. Feynman R. P. (1985). "Surely you're joking, Mr. Feynman!”: Adventures of a Curious Character / R. P. Feynman. - New York: W. W. Norton \& Company, 1985. - P. 350.

4. Feynman, R. P. What do you care what other people think? / R. P. Feynman. - New York: Bantam Books, 1989. - P. 256. - Retrieved from http://scilib-physics.narod.ru/Feynman/WDYC/en/contents.htm

5. Garner R. Humor in pedagogy: How ha-ha can lead to aha! / R. Garner // College Teaching. - 2006. - Vol. 54. - P. 177-179.

6. Holmes J. Politeness, power, and provocation: How humor functions in the workplace / J. Holmes // Discourse Studies. - 2000. - Vol. 2 (2). - P. 159-185.

7. Lee D. Humor in academic discourse / D. Lee // Journal of Language, Culture and Communication. - 2006. - Vol. 8 (3). - P. $49-68$.

8. LeVine H. The Great Explainer: The Story of Richard Feynman / H. LeVine. - Greensboro, North Carolina: Morgan Reynolds, 2009.

9. Martin R. Individual differences in uses of humor and their relation to psychological well-being: Development of the Humor Styles Questionnaire / R. Martin, P. Puhlik-Doris, G. Larsen, J. Gray, K. Weir // Journal of Research in Personality. - 2003. - Vol. 37 (1). - P. $48-75$.

10. Nesi H. Laughter in university lectures / H. Nesi // Journal of English for Academic Purposes. - 2012. - Vol. 11 (2). - P. 79-89.

11. Tait G. Laughing with the lecturer: the use of humour in shaping university teaching / G. Tait, J. Lampert, N. Bahr, P. Bennett // Journal of University Teaching \& Learning Practice. - 2015. - Vol. 12 (3).Retrieved from t:http://ro.uow.edu.au/jutlp/vol12/iss3/7

12. Torok S. Is humour an appreciated teaching tool? / S. Torok, R. McMorris, Lin Wen-Chi // College Teaching. - 2004. - Vol. 52 (1). - P. 14-2 